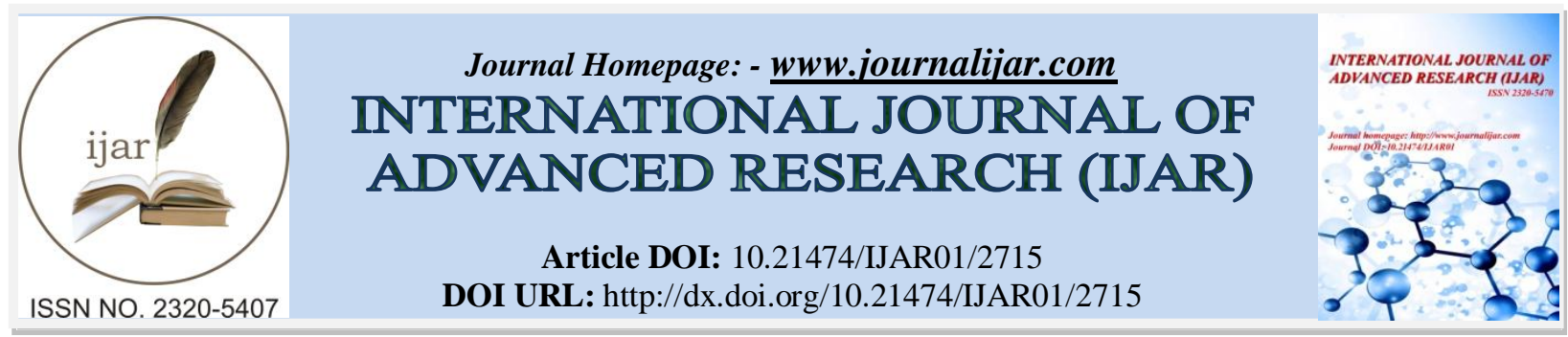

RESEARCH ARTICLE

\title{
UNWED MOTHERS IN ODISHA: ISSUES AND CHALLENGES
}

Dr. Pragyan Mohanty.

Lecturer Women's Studies, Ravenshaw University, Cuttack, Odisha.

\section{Manuscript Info}

Manuscript History

Received: 15 November 2016

Final Accepted: 17 December 2016

Published: January 2017

\section{Abstract}

Unwed Motherhood is emerging as a serious concern in our society where women are sexually exploited and literally left on the streets in a state of unwed pregnancy. The issue of unwed mothers is generating devastation in the conventional Odiya society. Odisha is a small culturally rich state of India having 30 districts and many famous tribes like Bonda, Bhumias, Kondhas, Santals, Sauras ect. Although Odisha has witnessed many positive changes resulting in development and growth an increased rate in crime and discriminatory behavior is observed towards its female citizens that is causing great unrest in the state. One such crime is the issue of unwed motherhood within the state especially in tribal areas. But as certain issues are more accepted in tribal areas like unwed motherhood or female headed households and their society has a matrilineal structure rather than a patriarchal one. But the above mentioned facts do not ensure egalitarian towards the tribal women. The notion that tribal women are less discriminated than their rural and urban counterparts is partly true as their society or community is more tolerant but a tribal woman is more discriminated in any given state or nation. Women in Odisha be it tribal women in particular or women in general have been facing discriminatory behavior in all aspects of life especially violence. And recently acts of violence against women have multiplied and are worryingly on the rise. One such issue that stems many times out of violence is unwed motherhood. This issue is plaguing the young female citizens in Odisha and is alarmingly on the rise.

Copy Right, IJAR, 2016,. All rights reserved.

Odisha has an extraordinary figure of young unwed mothers between the age of 13 to 30. These girls are easy targets for further exploitation as they are not accepted by the society and nor their families and are used for trafficking due to which many women are unaccounted for. This issue is further intensified in Odisha by frequently occurring Natural disasters making many people destitute and increasing their vulnerability. Experts believe there are 40,000 unwed mothers in Odisha, 70\% belonging to the tribal areas of Odisha. "Poverty" coupled with ignorance and innocence compound the problem of unwed mothers in tribal Odisha. The unwed mothers are treated as outcasts rejected by the society and are often viewed as prostitutes and even criminals.

A woman loses her dignity, pride and even her most basic human rights when she conceives a child without marriage. A woman usually faces all the problems of pregnancy even though making a child is a two way act the woman is left to take the burn if the child she is carrying is illegitimate, here the norms and culture of our society is 
eagerly sought after where reserving sex for marriage is seen in almost a scientific light solving many problems like sexually transmitted diseases, abortions and children out of wedlock. The women who are raped and sexually abused are left by themselves on the streets once they are discovered to be pregnant. The issue of unwed mothers is perhaps the most unforgivable crime against women. In the third world countries where illiteracy, poverty, poor health and backwardness have a major influence on the populace the ostracism that the unwed mothers attain is quite a phenomenon in determining the status of women in the society. Here not only a woman is mauled for life but her innocent child faces stigma throughout his/her life.

From my research it was revealed that unwed mothers usually belong to lower caste families as out of 200 respondent's majority of them belonged to schedule caste, schedule tribe and other backward classes. ((34.5 per cent) belonged to the Schedule Tribe and (31.5 per cent) belonged to Schedule Caste whereas only 18.5 per cent of them belong to General Category and 15.5 per cent of them belong to the Other Backward Classes.)) Low levels of awareness along with low literacy level were found to be major causes behind the number of unwed mothers among the SC and ST community. Unwed mothers enjoy relatively a better status in tribal societies than in non-tribal ones". This is because tribal society is matriarchal society where bride price system is observed instead of dowry system. Equality of opportunity, equal right, and equal pay for equal work are some of the practices which differentiate the status of tribal women from non-tribal women.

'Poverty' is one of the major factors behind unwed motherhood. Unwed mothers usually come from poor families as 84 per cent of them belonged to the lower income group. This shows that high level of awareness, high literacy rate are some of the reasons for absence of unwed motherhood problem among rich or affluent class or society. It was seen that unwed motherhood usually results from women falling prey to 'false promise to marry' (out of 200 respondents $68 \%$ victims of false promise to marry). In such cases, the women very easily succumb to the interest of the man primarily because of the fear of betrayal. The knowledge of contraception and the outcome of unsafe sex were found to be staggeringly low, deliberately ignored or due to unavailability of any such measures. And once discovered to be pregnant their partners assures them of marriage but disappears and the woman is left behind to answer the questions or more often the man responsible denies to the father. These victims are vulnerable to several kinds of exploitation. They are treated as commodities.

This becomes one of the factors responsible for trafficking in women as in many cases the accused tried to sell the victim to some brothels or labour contractors. But false promise to marry is not the sole reason of unwed motherhood. This is evident from the study as many of them (32.9 per cent) were victims of rape and in many cases rape by their relatives. In such type of case the abuser is known to the victim, they are members of the family or its inner circle. Most middle class Indians grow up in large extended families, open households where family and friends come and go thus the accused in such cases are known. The inquiry into domestic violence especially sexual abuse was one of the most complex, controversial challenges to investigate. As the dominance of sexual abuse at the domestic level is rampant. The prevalence of incest is strongly felt in India and is also evident in Odisha. Incestuous conduct is almost never consensual. Instead, it is rooted in physical force as well as familiar and other power which the abuser uses to pressure his victim. This is a terrible truth hidden in our society that we do not discuss let alone own up to. The cases of unwed mothers as a result of incest were very visible in my study. Many times these accused go unpunished as the victims face denial and they are not believed by other family members. These rapes, unless the news becomes public due to unavoidable reasons, are never reported. it is found that the highest numbers of respondents from the rape cases were victims within the family and by the relatives. This shows the growing number of domestic violence in our state.

Women are not safe from physical abuse and torture even within the blood ties and the four walls of her home. Rape or sexual harassment at work place is also seen as a factor responsible for unwed motherhood. Unemployment is rampant these days so to retain a job has become very tough especially in the unorganized sector and it was found that, out of 200 respondents $4.7 \%$ were unwed mothers due to rape at work place. In a case study in Kalahandi a 16 year old girl who worked as a daily wage labourer was the victim of rape by the contractor who control these daily wage labourers and took them to distance places to work, the girls who go without any family members are the main targets for sexual assault by these contractors and other daily wage labourers. 25 per cent of unwed mothers' were victimized by strangers, these strangers were mostly found to be migrant workers. Migrant workers are becoming a major threat to the local young women and girls especially at grass root level. The level of awareness to different governmental policies and programmes and institutions for the women in general and destitute women in particular was found to be very low among the respondents as the ICDS programme is the oldest welfare programme for 
women. But a large majority of respondents ( 84 per cent) are not yet aware of this. The Government of India has enacted a number of laws for women's liberty, rights, equality and development, but the respondents were not aware of a number of such laws like the protection of women from Domestic Violence Act". Only 12.5 per cent are aware of this Act and 87.5 per cent are not so. This shows that the government should take extra care to spread awareness about this problem because it is growing very rapidly. The study shows that rural and tribal women usually face the severity of the problem of unwed motherhood. This problem is magnified by poverty, ignorance, social stigma which forces these women towards humiliation which act as a hindrance in the path of their development. These women rarely become members of social, political and professional organizations due to the rigidity of our society in dealing with this problem. The unwed mothers are treated like out casts even their basic human rights are denied by the society, they were not accepted by the women of the same locality with the fear of polluting the public places hence are not allowed to the public places like ponds, river Ghats ect and they were not accepted easily even as an employee. Thus a large number of the respondents (43.2 percent) said that they were driven out of the job immediately after their unwed mother status was disclosed.

The futures of those children who remain with the unwed mothers are a source of primary concern, and attention needs to be given towards their welfare. It is seen that 57 percent of the respondents expressed the desire to put the child up for adoption. Some of the aspects that compel a mother to put her child up for adoption were the negative attitude of the society regarding the identity of the child's father, the possibility of marriage of the victims, financial crunch in raising the child etc. It is seen that 19 percent unwed mothers even blame the child for their present fate; this response especially noted among some of the mentally challenged women. Whereas 12 percent of the respondents wanted to keep the child as a proof of the relationship with the person involved.

\section{Suggestions:-}

From the above study two major factors come into focus: the first one to eradicate this problem and the second one is if cases of unwed mothers are found care should be taken to improve not only their life but also the life of their children. From the present study certain suggestions have come into perspective i.e., all efforts should be made to identify and get the accused, and implement stringent laws and strict punishment along with financial penalty. Awareness campaign regarding welfare and legal measure should be given top priority and there should be women police station or Mahila desk in all the villages, special emphasis should be on awareness regarding safety measures like use of contraception, risks factors HIV/AIDs, and Sexually transmitted diseases etc should be imparted.

The society needs to be more sensitized about the problem of unwed mothers, the society should adopt measures to avoid domestic violence, mothers of the young girl along with their daughter should be made aware of the problems and how to protect themselves from such type of crime.

A major problem that cannot be ignored is poverty, thus more number of SHGs and microfinance scheme should be made available to rural women to empower them economically. Land rights to women should be given so that they could have a share on the labour they put in. The welfare schemes like Short Stay Homes and Swadhar Shelter homes for destitute should be available in rural and tribal areas so as to give these victims immediate relief instead of only being available at urban areas. Special attention needs to be given to rehabilitate them within the time span allotted to these homes. And special attention needs to be given to the children who live with these unwed mothers.

Print and electronic media should be active in the rural and tribal areas to spread the message of safe sex and knowledge regarding the risks involved in unprotected sex through pamphlets, showing documentaries on the life of unwed mothers and the life of their innocent children in schools and colleges.

These measures will in still in the youth greater sense of awareness and responsibility. As false promise to marry is one of the most common causes of unwed motherhood women must be educated against this act.

The severe laws and punishments for this crime should be highlighted. And most importantly the DNA test should be made available for such victims and not only to special cases.

Women's commission role should be highlighted and a women cell of representing the Commission should be established in every nook and corner. 
Voluntary organizations should actively spread awareness regarding different welfare schemes and developmental programme in the rural areas. They should also identify unwed mothers and try to give them justice with the help of the police. They should provide training programmes to make these women economically independent.

Government hospitals, bus stands and railway stations are the areas where the unwed mothers are generally found. Thus "help desk" should be established in these areas.

It is imperative to initiate these steps not only to improve the conditions of unwed mothers in the state but to eradicate and prevent this problem from taking a strong hold in our society.

\section{References:-}

1. Afshar, Haleh. (1996) (ed.) Women and Politics in the Third World. Rutledge: London,

2. Agarwal C. M. (1993) Dimensions of Indian Womanhood. Shri Almora Book Depot: Delhi

3. Agarwal, Bina. (1994) A Field of One's Own. Cambridge University Press: Cambridge

4. Ahuja Ram (1998). Violence Against Women. Rawat Publication: Jaipur

5. Das Pragyan (2012). Status of Unwed Mothers in Odisha: An Analysis. Laplambert Publications: Saarbrucken, Germany. 